\title{
Archival pop-off tag tracking of Greenland sharks Somniosus microcephalus in the High Arctic waters of Svalbard, Norway
}

\author{
Aaron T. Fisk ${ }^{1, *}$, Christian Lydersen ${ }^{2}$, Kit M. Kovacs ${ }^{2}$ \\ ${ }^{1}$ University of Windsor, Great Lakes Institute for Environmental Research, 401 Sunset Avenue, Windsor, Ontario N9B 3P4, \\ Canada \\ ${ }^{2}$ Norwegian Polar Institute, Fram Centre, Tromsø 9296, Norway
}

\begin{abstract}
The Greenland shark Somniosus microcephalus is the largest fish in Arctic waters and a significant predator that is likely numerous, but little is known about its movement patterns or habitat preferences. In June 2008 and 2009, 20 archival pop-off tags were deployed on Greenland sharks in coastal waters in Svalbard, Norway $\left(\sim 80^{\circ} \mathrm{N}\right)$, to address this knowledge gap. Over the period June to December, 14 of the tags reported data. The swimming depth of the sharks was $111 \pm 74 \mathrm{~m}$ (mean $\pm \mathrm{SD}$ ), but they occupied waters from the surface down to a depth of at least $1560 \mathrm{~m}$ (the depth limit of the tags), which is the deepest confirmed record for this species. The sharks displayed a wide range of depths within each $6 \mathrm{~h}$ time bin collected by the tags, with no obvious diel movement pattern. They experienced temperatures from -1.5 to $7.4^{\circ} \mathrm{C}$ (mean $\pm \mathrm{SD}=$ $3.8 \pm 1.4^{\circ} \mathrm{C}$ ). The average depth of swimming increased and temperatures experienced by the sharks decreased from June through December. Most individuals moved north from the tagging area, and travelled a range of distances during their variable deployment times, but most tags popped off $<500 \mathrm{~km}$ from the tagging site. The average distance travelled varied from 0.6 to $16.6 \mathrm{~km} \mathrm{~d}^{-1}$. Two sharks travelled 725 and $980 \mathrm{~km}$, respectively, representing the most northerly $\left(82.4^{\circ} \mathrm{N}\right)$ and easterly $\left(40.8^{\circ} \mathrm{E}\right)$ locations documented for this species. The movements of the tagged sharks suggest that this species likely ranges broadly in northern waters and likely hunts throughout the water column in Arctic seas.
\end{abstract}

KEY WORDS: Distribution - Elasmobranch - Polar · Pop-up archival tags · Swimming depth · Water temperature

Resale or republication not permitted without written consent of the publisher

\section{INTRODUCTION}

Advances in satellite telemetry technology have provided new insights into the movement, depth and water temperatures occupied by various fishes, including sharks (Block 2005). Some telemetric studies also provide specific details about behavior, such as foraging patterns (Sims et al. 2008). The data generated via telemetry have improved our understanding of important habitat preferences and the influence of oceanographic conditions on shark ecology, which is critical information for their management and conservation. Currently, only very limited information is available regarding the movement patterns and habitats occupied by the Greenland shark Somniosus microcephalus. This species is one of the largest elasmobranchs on the planet and one of only 2 shark species that regularly inhabits Arctic waters (Benz et al. 2004).

The known geographic range of the Greenland shark extends from the northern reaches of Baffin Bay southward to the east coast of Nova Scotia in the West Atlantic and from waters around Svalbard southward in deep waters as far as Spain along the 
European coast in the Northeast Atlantic (MacNeil et al. 2012). There have also been observations of Somniosus sp. in deep waters (>2000 m) off the coast of Georgia, USA (Herdendorf \& Berra 1995), and in the Gulf of Mexico, but these individuals have not been confirmed to be S. microcephalus (Benz et al. 2007).

The movements and habitat preferences of Greenland sharks across the species' vast geographic range are largely unknown. Traditional fish marking studies on the west coast of Greenland in the late 1940s documented that 1 shark travelled $\sim 1500 \mathrm{~km}$, but most tags were recovered in the general tagging area (Hansen 1963), although the overall tag recovery rate was low and coastally biased. Three pop-off archival tags were deployed on Greenland sharks in the St Lawrence Estuary, Quebec, Canada, for periods up to $66 \mathrm{~d}$. These sharks generally inhabited deep (325 to $352 \mathrm{~m})$, cold $\left(-1.1\right.$ to $\left.8.6^{\circ} \mathrm{C}\right)$ water, but they did spend time near shore in shallower water $(<60 \mathrm{~m})$, and they displayed some diel patterns in their vertical movements (Stokesbury et al. 2005).

Greenland sharks are commonly observed in the North Atlantic by researchers, fishermen and sealers (Dunbar \& Hildebrand 1952, Templeman 1963), but no actual abundance estimates have been conducted. There was significant commercial fishing for this species in deep water $(>500 \mathrm{~m}$ ) off the east and west coasts of Greenland between 1900 and 1960. At the height of the fishery in West Greenland in the 1940s, reported annual catches were estimated to be $\sim 50000$ ind. (Jensen 1948), and to the east, $>10000$ ind. were caught annually up until the end of the 1940s (Hoel 1949). Norwegian catches were also very large (Hoel 1949), and although the numbers of sharks harvested were not reported, it is likely that combined catches were $>100000$ ind. per year based on the amount of liver or liver oil delivered to the market. The lack of population data and reproductive metrics makes it difficult to assess the effect of the historical harvests on the Greenland shark population. The fishery for this species terminated decades ago, when synthetic oils replaced shark oil in the market, and it is likely that the population has increased during the intervening period. Changes in biomass and population size of large marine vertebrates can have profound effects on ecosystem functioning (Pershing et al. 2010), perhaps particularly in Arctic waters that have fairly simple food webs and limited annual primary production.

Given the potentially large population size, wide geographic range and broad feeding niche, which includes a top predator component (Fisk et al. 2002, McMeans et al. 2010, LeClerc et al. 2012), there is a need to understand the movements and habitat preferences of Greenland sharks. To address this knowledge gap, 20 ind. were tagged with archival pop-off tags in a fjord in western Svalbard, Norway, to collect depth, temperature and movement data for this littlestudied elasmobranch. This information is of particular relevance given the evidence that these sharks prey on marine mammals in Arctic waters (LeClerc et al. 2011) where changing ice and climate conditions are a concern for marine mammals and ecosystem health (e.g. Johannessen \& Miles 2010, Kovacs et al. 2011, 2012).

\section{MATERIALS AND METHODS}

\section{Study site, shark capture and tag attachment}

Greenland sharks were captured in Kongsfjorden, Svalbard (Fig. 1), from 10 to 12 June 2008 and 16 to 22 June 2009. All of the sharks were captured using long-lines (6 mm nylon) with $2.0 \mathrm{~m}$ long stainless steel lead lines (3 mm) and large (25 cm long) steel hooks baited with bearded seal blubber (and skin). The distance between hooks was $\sim 50 \mathrm{~m}$, and each line consisted of 20 to 35 hooks. The long-lines were set across bathymetric gradients starting at depths of $\sim 60$ to $80 \mathrm{~m}$ and ending at depths of $\sim 260$ to $300 \mathrm{~m}$ (see LeClerc et al. 2012 for specific details on locations of set lines). Weather permitting, the long-lines were pulled after $2 \mathrm{~d}$ in 2008 and after $1 \mathrm{~d}$ in 2009. In 2008, the fieldwork was conducted from a $15 \mathrm{~m}$ long fishing boat, the 'Viking Explorer', and in 2009 from the $60 \mathrm{~m}$ long RV 'Lance'.

Sharks were chosen for pop-off archival tag (Mk10 pop-up archival transmitting tag [PAT], Wildlife Computers) deployments based on their condition when brought to the surface; only sharks that were hooked in the mouth, not bleeding from the gills and with minimal dermal abrasion were tagged. An individual chosen for tagging was secured to the side of a zodiac boat using the hook line and a padded rope was placed around the caudal peduncle. The shark was then pulled a few meters away from the fishing boat for measurement and tagging, which took place in the water. In 2008, total length and sex were determined immediately after capture, and the shark was tagged, the hook was removed, and the shark was released. In 2009, after a selected shark had been pulled away from the fishing boat, 2 small floats were attached to it via a $5 \mathrm{~m}$ rope to the caudal peduncle, the hook was removed, and the shark was released attached to the float. After the whole line was pulled, 


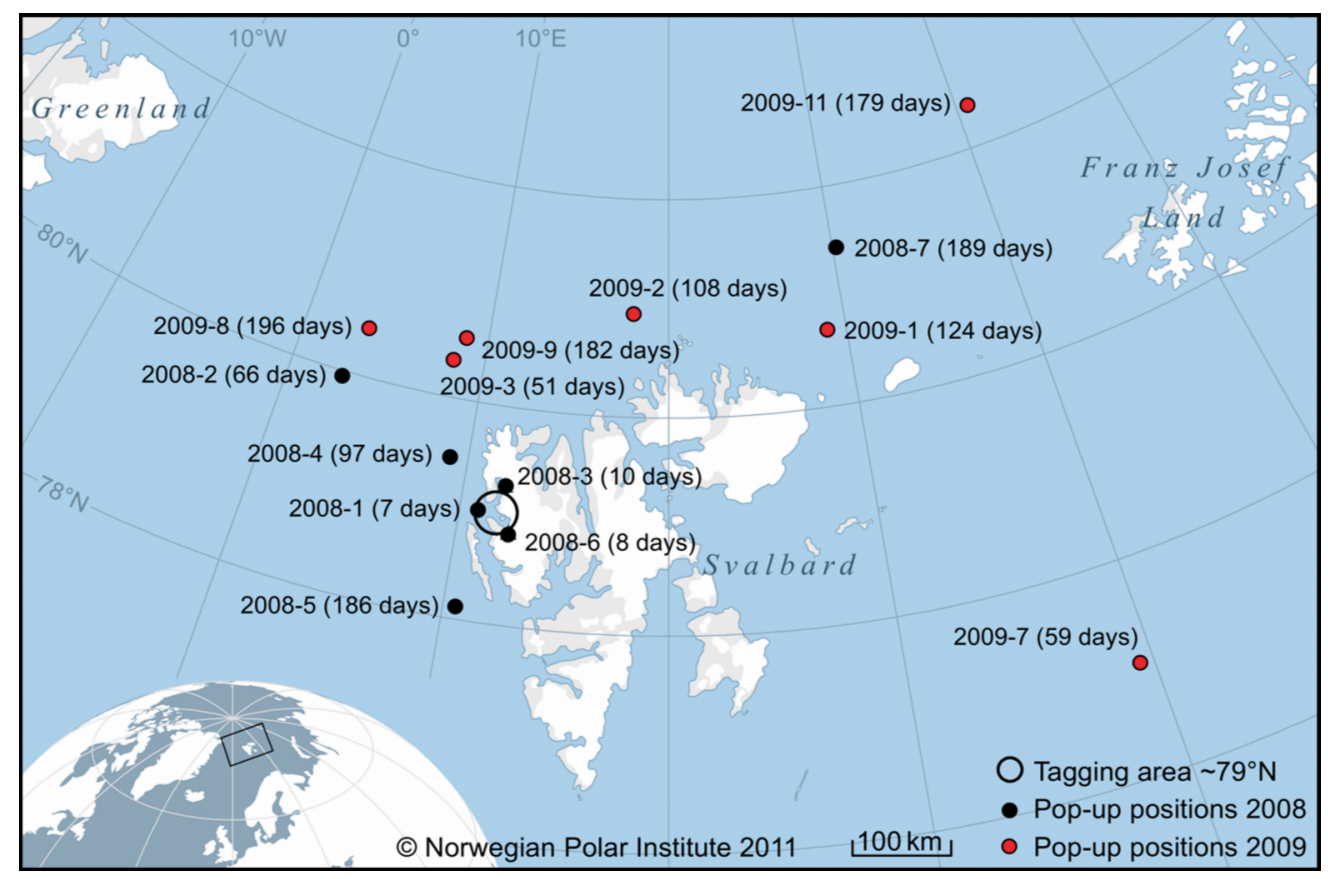

Fig. 1. Somniosus microcephalus. Tagging location (circle), pop-off location and days at liberty for 14 individuals tagged with pop-off archival satellite tags in June of 2008 and 2009 in Kongsfjorden, Svalbard, Norway

the shark(s) were reassessed (all sharks were active and lively), and the total length, girth and sex was determined. Each shark was then tagged and released. Body masses of released sharks were estimated based on their length to girth ratio. In 2009, a diver observed and videotaped the sharks after release. To 7 of the PAT tagged sharks small accelerometers were attached at the dorsal ridge for $24 \mathrm{~h}$ deployments (Table 1), the results of which are reported by Watanabe et al. (2012). Both the observations and accelerometers indicated active, normal swimming by the sharks following release.

The PATs were secured to the sharks by inserting a nylon umbrella dart $\sim 10 \mathrm{~cm}$ into the dorsal muscle just lateral to the first dorsal fin. The dart was angled to engage the pterygiophores beneath the dorsal fin. The umbrella tip was attached to the PAT with a monofilament leader (400 lb test). In 2008, each tag was fitted with an emergency release device (provided by the manufacturer) that released the instrument at a depth of $1500 \mathrm{~m}$ (which is the maximum nominal safe depth for tag operation). This device was not used in 2009.

The PATs were programmed to record depth $( \pm 0.5 \mathrm{~m})$, temperature $\left( \pm 0.1^{\circ} \mathrm{C}\right)$ and light intensity at $10 \mathrm{~s}$ intervals for a period of 3 to $12 \mathrm{mo}$ (see Table 1 ). The data were internally binned within $6 \mathrm{~h}$ intervals, and the summarized data were transmitted to an Argos satellite when the tag floated up to the surface after release of the PAT from the shark. Binned data included minimum, maximum and mean depth, temperature and light level for each $6 \mathrm{~h}$ period. In 2008, PATs were programmed to release from the shark if a constant depth was maintained for a period of $96 \mathrm{~h}$ (which might indicate that a shark had died). This function was not used in 2009. PATs were programmed to release at 3,6 and 12 mo intervals (see Table 1).

\section{Statistical analysis}

A linear mixed-effects model was used to assess the influence of total length, sex, month and time-ofday (based on binning of data, there were 4 time periods for each day: 00:01 to $6: 00 h_{i} 06: 01$ to $12: 00 h_{\text {; }}$ 12:01 to $18: 00 \mathrm{~h}$; and 18:01 to $24: 00 \mathrm{~h}$ ) on the average depth and average temperature (for $6 \mathrm{~h}$ binned data), as well as to explore possible interactions between month and time-of-day (log [average depth or average temperature $]=$ Total length + Sex + Time period + Month $+[$ Total length $\times$ Sex $]+[$ Total length $\times$ Time period $]+[$ Total length $\times$ Month $]+[$ Sex $\times$ Time period $]+[$ Sex $\times$ Month $]+[$ Time period $\times$ Month $]$ ) 
Table 1. Somniosus microcephalus. Biological and pop-off archival tag data for 20 Greenland sharks tagged around Svalbard in 2008 and 2009. ID: identification number. F: female. M: male. TL: total length. DAL: days at liberty; Dnr: tag did not report. See Fig. 1 for tagging location. To sharks no. 2009-1, 2009-4, 2009-7 and 2009-11 small accelerometers were attached at the dorsal ridge for $24 \mathrm{~h}$ deployments. lat.: latitude $\left({ }^{\circ} \mathrm{N}\right)$, long.: longitude $\left({ }^{\circ} \mathrm{E}\right)$

\begin{tabular}{|c|c|c|c|c|c|c|c|c|c|}
\hline \multirow{2}{*}{$\begin{array}{l}\text { Shark } \\
\text { ID } \\
2008-1\end{array}$} & \multirow{2}{*}{$\begin{array}{c}\text { Sex } \\
\text { F }\end{array}$} & \multirow{2}{*}{$\begin{array}{c}\begin{array}{c}\mathrm{TL} \\
(\mathrm{cm})\end{array} \\
340\end{array}$} & \multirow{2}{*}{$\begin{array}{l}\text { Deployment } \\
10 \text { Jun } 2008\end{array}$} & \multirow{2}{*}{$\begin{array}{c}\text { Date of } \\
\text { pop-off } \\
15 \text { Sep } 2008\end{array}$} & \multirow{2}{*}{$\begin{array}{c}\text { Reporting } \\
17 \text { Jun } 2008\end{array}$} & \multirow{2}{*}{$\begin{array}{c}\text { DAL } \\
\text { (d) } \\
8\end{array}$} & \multirow{2}{*}{$\begin{array}{c}\begin{array}{c}\text { Pop-off } \\
\text { at }\end{array} \\
\text { lat./long. }\end{array}$} & \multicolumn{2}{|c|}{$\begin{array}{c}\text { Distance } \\
\text { travelled } \\
(\mathrm{km})^{\mathrm{a}}\left(\mathrm{km} \mathrm{d}^{-1}\right)^{\mathrm{b}}\end{array}$} \\
\hline & & & & & & & & 20 & 2.5 \\
\hline $2008-2$ & M & 330 & 10 Jun 2008 & 15 Sep 2008 & 10 Jul 2008 & 66 & $79.97 / 2.80$ & 220 & 3.3 \\
\hline $2008-3$ & M & 295 & 10 Jun 2008 & 15 Sep 2008 & 20 Jun 2008 & 10 & $79.29 / 12.00$ & 35 & 3.5 \\
\hline 2008-4 & $\mathrm{F}$ & 275 & 10 Jun 2008 & 15 Sep 2008 & 15 Sep 2008 & 97 & $79.48 / 9.06$ & 85 & 0.9 \\
\hline $2008-5$ & $\mathrm{~F}$ & 307 & 12 Jun 2008 & 15 Dec 2008 & 15 Dec 2008 & 186 & $78.13 / 10.54$ & 120 & 0.6 \\
\hline $2008-6$ & M & 320 & 12 Jun 2008 & 15 Dec 2008 & 13 Jun 2008 & 8 & $78.86 / 12.46$ & $<10$ & 1.3 \\
\hline 2008-7 & $\mathrm{F}$ & 310 & 12 Jun 2008 & 15 Dec 2008 & 15 Dec 2008 & 189 & $81.45 / 30.24$ & 515 & 2.7 \\
\hline $2008-8$ & M & 300 & 12 Jun 2008 & 15 Dec 2008 & Dnr & - & - & - & - \\
\hline 2008-9 & $\mathrm{F}$ & 370 & 12 Jun 2008 & 15 Jun 2009 & Dnr & - & - & - & - \\
\hline 2009-1 & M & 300 & 16 Jun 2009 & 30 Sep 2009 & 18 Oct 2009 & 124 & $80.70 / 28.94$ & 475 & 3.8 \\
\hline 2009-2 & M & 305 & 16 Jun 2009 & 30 Sep 2009 & 2 Oct 2009 & 108 & $80.95 / 17.99$ & 305 & 2.8 \\
\hline 2009-3 & M & 285 & 22 Jun 2009 & 30 Sep 2009 & 12 Aug 2009 & 51 & 80.31/8.31 & 180 & 3.5 \\
\hline 2009-4 & M & 330 & 16 Jun 2009 & 29 Jun 2010 & Dnr & - & - & - & - \\
\hline $2009-5$ & $\mathrm{~F}$ & 367 & 16 Jun 2009 & 29 Jun 2010 & Dnr & - & - & - & - \\
\hline $2009-6$ & M & 310 & 17 Jun 2009 & 29 Jun 2010 & Dnr & - & - & - & - \\
\hline $2009-7$ & $\mathrm{~F}$ & 305 & 22 Jun 2009 & 29 Jun 2010 & 20 Aug 2009 & 59 & $77.04 / 39.44$ & 980 & 16.6 \\
\hline 2009-8 & $\mathrm{F}$ & 340 & 16 Jun 2009 & 15 Dec 2009 & 29 Dec 2009 & 196 & $80.44 / 3.45$ & 245 & 1.3 \\
\hline 2009-9 & M & 310 & 16 Jun 2009 & 15 Dec 2009 & 15 Dec 2009 & 182 & $80.56 / 8.78$ & 205 & 1.1 \\
\hline 2009-10 & M & 330 & 17 Jun 2009 & 15 Dec 2009 & Dnr & - & - & - & - \\
\hline 2009-11 & M & 300 & 22 Jun 2009 & 15 Dec 2009 & 18 Dec 2009 & 179 & $82.38 / 40.83$ & 725 & 4.1 \\
\hline
\end{tabular}

From the latitude where the sharks were tagged $\left(\sim 80^{\circ} \mathrm{N}\right)$, they moved from a period of $24 \mathrm{~h}$ of light (June to September) to a period of $24 \mathrm{~h}$ dark (November and December). The Time-of-day $\times$ Month interactions were not significant, and thus, no effort was made to correct for light level. Because individual sharks included multiple observations, random intercepts were included for individual sharks, to account for both the shark-level variability and uneven sample sizes among individuals. All analyses were performed in R (R Development Core Team 2010); values are presented as means \pm 1 SD unless otherwise indicated.

\section{RESULTS}

Fourteen of the 20 PATs deployed reported data to ARGOS. Several of the tags released prematurely, 3 of them remaining on the individuals for $\leq 10 \mathrm{~d}$. Tag no. 2008-6 provided no usable depth or temperature data. Nine tags released at or very close to their designated termination times (Table 1). Data records lasted from 8 to $196 \mathrm{~d}$ (average $104.5 \pm 72.4 \mathrm{~d}$ ). The total number of tracking days for all individuals was 1463, but the completeness of data records varied markedly, ranging from 0.8 to $100 \%$ of the time, with data being reported from a total of $34.1 \%$ of the time that all sharks combined carried tags (Table 2). No usable light level data were collected despite the fact that many of the sharks approached or reached the surface.

Upon release, PATs floated to the surface and uplinked to Argos satellites, providing a location fix that is close to the shark's position when the record terminated. Most of the sharks moved northward, only 2 sharks had tags release south of the deployment area (Fig. 1, Table 1). According to these location data, the minimum distances travelled by the sharks varied from 20 to $980 \mathrm{~km}$, and the average distance travelled ranged from 0.6 to $16.6 \mathrm{~km} \mathrm{~d}^{-1}$ (Table 1). It must be stressed that these are crude measurements of the minimal distance and speeds of travel. The sharks travelled within a wide range of depths but mainly occupied the top $150 \mathrm{~m}$ of the water column (Fig. 2). Most of the sharks spent at least some time in water $<20$ and $>300 \mathrm{~m}$, with occasional dives to depths that were much greater (Table 2). Approximately one-third of the sharks approached the surface (0 to $8 \mathrm{~m}$ ), and 1 shark reached a depth of $1560 \mathrm{~m}$ (which engaged the release mechanism on the tag). An initial mixed effects model using only shark iden- 
Table 2. Somniosus microcephalus. Depth $(\mathrm{m})$ and temperature (Temp., ${ }^{\circ} \mathrm{C}$ ) data (mean $\pm \mathrm{SD}$ range minimum to maximum) for Greenland sharks tagged around Svalbard in 2008 and 2009. Shark 2008-6 was only at liberty for 8 d, and the depth and temperature data showed no variation

\begin{tabular}{|c|c|c|c|c|c|c|c|c|c|}
\hline \multirow{2}{*}{$\begin{array}{l}\text { Shark } \\
\text { ID }\end{array}$} & \multirow[b]{2}{*}{ Mean } & \multirow{2}{*}{\multicolumn{2}{|c|}{$\begin{array}{l}\text { Min. - max. Difference } \\
\text { a }\end{array}$}} & \multirow[b]{2}{*}{ Difference $^{b}$} & \multirow[b]{2}{*}{ Mean } & \multirow{2}{*}{$\begin{array}{l}\text { Temp } \\
\text { Min. - max. }\end{array}$} & \multirow{2}{*}{ Difference ${ }^{\mathrm{c}}$} & \multirow[b]{2}{*}{ Difference $^{\mathrm{d}}$} & \multirow{2}{*}{$\begin{array}{l}\% \text { data } \\
\text { reported }\end{array}$} \\
\hline & & & & & & & & & \\
\hline \multicolumn{10}{|c|}{ Individual sharks } \\
\hline 2008-1 & $112 \pm 40$ & $16-296$ & $119 \pm 54$ & $32-256$ & $1.6 \pm 0.3$ & $1.8-3.6$ & $0.7 \pm 0.5$ & $0.2-2.0$ & 100 \\
\hline $2008-2$ & $191 \pm 115$ & $16-1560$ & $170 \pm 115$ & $64-984$ & $3.2 \pm 0.8$ & $0-5.0$ & $1.5 \pm 0.5$ & $0.2-3.0$ & 44.7 \\
\hline $2008-3$ & $200 \pm 121$ & $0-368$ & $131 \pm 73$ & $48-368$ & $1.2 \pm 0.8$ & $0-4.8$ & $1.5 \pm 0.6$ & $0.2-3.2$ & 95.5 \\
\hline $2008-4$ & $116 \pm 39$ & $8-560$ & $74 \pm 57$ & $16-544$ & $3.8 \pm 1.0$ & $0-6.8$ & $1.1 \pm 0.8$ & $0-4.4$ & 98.7 \\
\hline $2008-5$ & $135 \pm 76$ & $8-688$ & $123 \pm 87$ & $30-520$ & $4.4 \pm 0.9$ & $0-6.6$ & $1.2 \pm 1.0$ & $0-5.6$ & 76.7 \\
\hline $2008-6$ & - & - & - & - & - & - & - & - & - \\
\hline $2008-7$ & $140 \pm 55$ & $48-528$ & $100 \pm 75$ & $16-440$ & $4.0 \pm 0.8$ & $0-5.6$ & $1.0 \pm 0.9$ & $0.2-4.8$ & 19.7 \\
\hline 2009-1 & $81 \pm 41$ & $16-184$ & $109 \pm 62$ & $16-280$ & $4 \pm 1.1$ & $1.8-5.6$ & $1.1 \pm 0.9$ & $0-3.8$ & 17.1 \\
\hline 2009-2 & $62 \pm 42$ & $16-616$ & $125 \pm 94$ & $16-512$ & $4.6 \pm 1.2$ & $0-7.4$ & $1.7 \pm 1.1$ & $0.2-4.0$ & 60.0 \\
\hline $2009-3$ & $132 \pm 125$ & $48-1192$ & $140 \pm 105$ & $24-592$ & $3.9 \pm 1.1$ & $0-6.2$ & $1.3 \pm 0.7$ & $0.2-3.2$ & 54.9 \\
\hline $2009-7$ & $78 \pm 34$ & $0-352$ & $79 \pm 34$ & $16-232$ & $1.5 \pm 1.5$ & $-1.5-5.2$ & $0.7 \pm 0.5$ & $0-3.2$ & 83.9 \\
\hline $2009-8$ & $71 \pm 4.3$ & $40-288$ & $139 \pm 90$ & $40-216$ & $4.2 \pm 0.4$ & $0-5.2$ & $3.2 \pm 2.1$ & $0.8-4.4$ & 0.8 \\
\hline 2009-9 & $70 \pm 35$ & $8-976$ & $106 \pm 91$ & $16-784$ & $4.3 \pm 1.0$ & $0-6.2$ & $1.2 \pm 1.0$ & $0-5.8$ & 46.4 \\
\hline $2009-11$ & $119 \pm 55$ & $80-440$ & $156 \pm 63$ & $32-240$ & $4.1 \pm 0.6$ & $2.0-5.2$ & $1.0 \pm 0.6$ & $0.2-2.2$ & 3.6 \\
\hline \multicolumn{10}{|c|}{ All sharks } \\
\hline Jun & $105 \pm 65$ & $0-488$ & $104 \pm 55$ & $24-368$ & $3.2 \pm 1.3$ & $-1.5-6.2$ & $1.2 \pm 0.6$ & $0.2-3.6$ & 25.0 \\
\hline Jul & $112 \pm 91$ & $16-1560$ & $107 \pm 90$ & $16-984$ & $3.5 \pm 1.4$ & $0-6.2$ & $1.1 \pm 0.8$ & $0-5.2$ & 50.7 \\
\hline Aug & $102 \pm 49$ & $16-976$ & $104 \pm 94$ & $16-784$ & $3.7 \pm 1.6$ & $0-7.2$ & $1.4 \pm 1.0$ & $0-5.4$ & 30.3 \\
\hline Sept & $96 \pm 38$ & $8-616$ & $111 \pm 95$ & $16-544$ & $4.6 \pm 1.1$ & $0-7.4$ & $1.5 \pm 1.2$ & $0-5.2$ & 16.4 \\
\hline Oct & $117 \pm 55$ & $16-816$ & $142 \pm 96$ & $32-760$ & $4.6 \pm 0.7$ & $0-6.2$ & $1.4 \pm 1.2$ & $0.2-5.8$ & 27.7 \\
\hline Nov & $130 \pm 94$ & $16-688$ & $109 \pm 76$ & $16-416$ & $4.7 \pm 0.6$ & $0-5.8$ & $1.0 \pm 0.9$ & $0-5.2$ & 36.1 \\
\hline Dec & $164 \pm 103$ & $8-536$ & $137 \pm 69$ & $24-304$ & $4.3 \pm 0.7$ & $0-5.4$ & $1.0 \pm 0.8$ & $0-4.2$ & 20.1 \\
\hline All & $111 \pm 74$ & $0-1560$ & $110 \pm 84$ & $16-984$ & $3.8 \pm 1.4$ & $-1.5-7.4$ & $1.2 \pm 0.9$ & $0-5.8$ & 34.1 \\
\hline \multicolumn{10}{|c|}{$\begin{array}{l}\text { a Mean difference in maximal and minimal depths for each } 6 \mathrm{~h} \text { period binned by the PAT; }{ }^{\mathrm{b}} \text { minimal and maximum depth } \\
\text { difference are the smallest recorded differences between minimum and maximum depth for any } 6 \mathrm{~h} \text { period binned by the } \\
\text { PAT; }{ }^{c} \text { mean difference in maximal and minimal temperatures for each } 6 \mathrm{~h} \text { period binned by the PAT. }{ }^{\mathrm{d}} \text { Minimal and maxi- } \\
\text { mum temperature difference are the smallest recorded differences between minimum and maximum temperatures for any } \\
6 \mathrm{~h} \text { period binned by the PAT }\end{array}$} \\
\hline
\end{tabular}

tification numbers (null model) found that variation in average depth was somewhat greater within individuals than among individuals. A second, full mixed effects model that included covariate information showed that total length and time of day had little effect on depth, but sex, month and the Sex $\times$ Month interaction did show differences. The effect of sex was small overall $(<1 \mathrm{~m}$ overall difference between sexes based on mean values), but greater differences occurred when month-by-month data were examined. However, it should be noted that there were more than twice as many data points for females ( $\mathrm{n}=1672$ ) than for males $(n=642)$. Model output suggested that males were found at greater depths (all means \pm SD) in June, July and October $(119 \pm 85,129 \pm 14$ and $130 \pm 55 \mathrm{~m}$, respectively) compared to females (94 \pm 35 , $103 \pm 50$ and $110 \pm 48 \mathrm{~m}$, respectively), but males swam more shallowly in August and September $(81 \pm 45$ and $83 \pm 40 \mathrm{~m}$, respec- tively) than females $(109 \pm 48$ and $101 \pm 37 \mathrm{~m}$, respectively). There were only 5 data points for males in November $(73 \pm 3.3 \mathrm{~m})$ and none in December, but females were at their greatest depths in these months

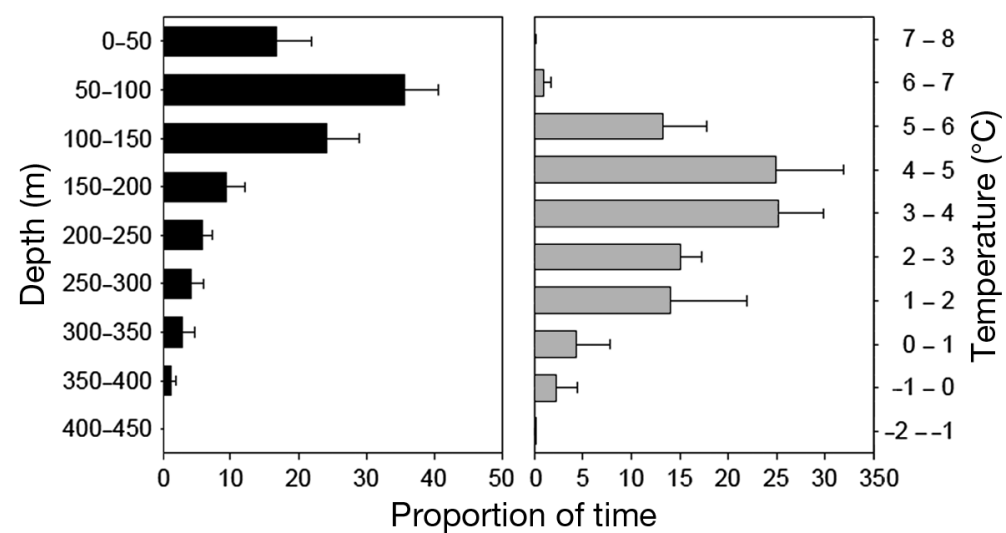

Fig. 2. Somniosus microcephalus. Depth and temperature records (mean $+1 \mathrm{SE}$ ) for Greenland sharks tagged with pop-off archival satellite tags in Kongsfjorden, Svalbard, Norway, in June 2008 and 2009. Note that the $y$-axes for temperature and depth are not correlated between the 2 graphs 


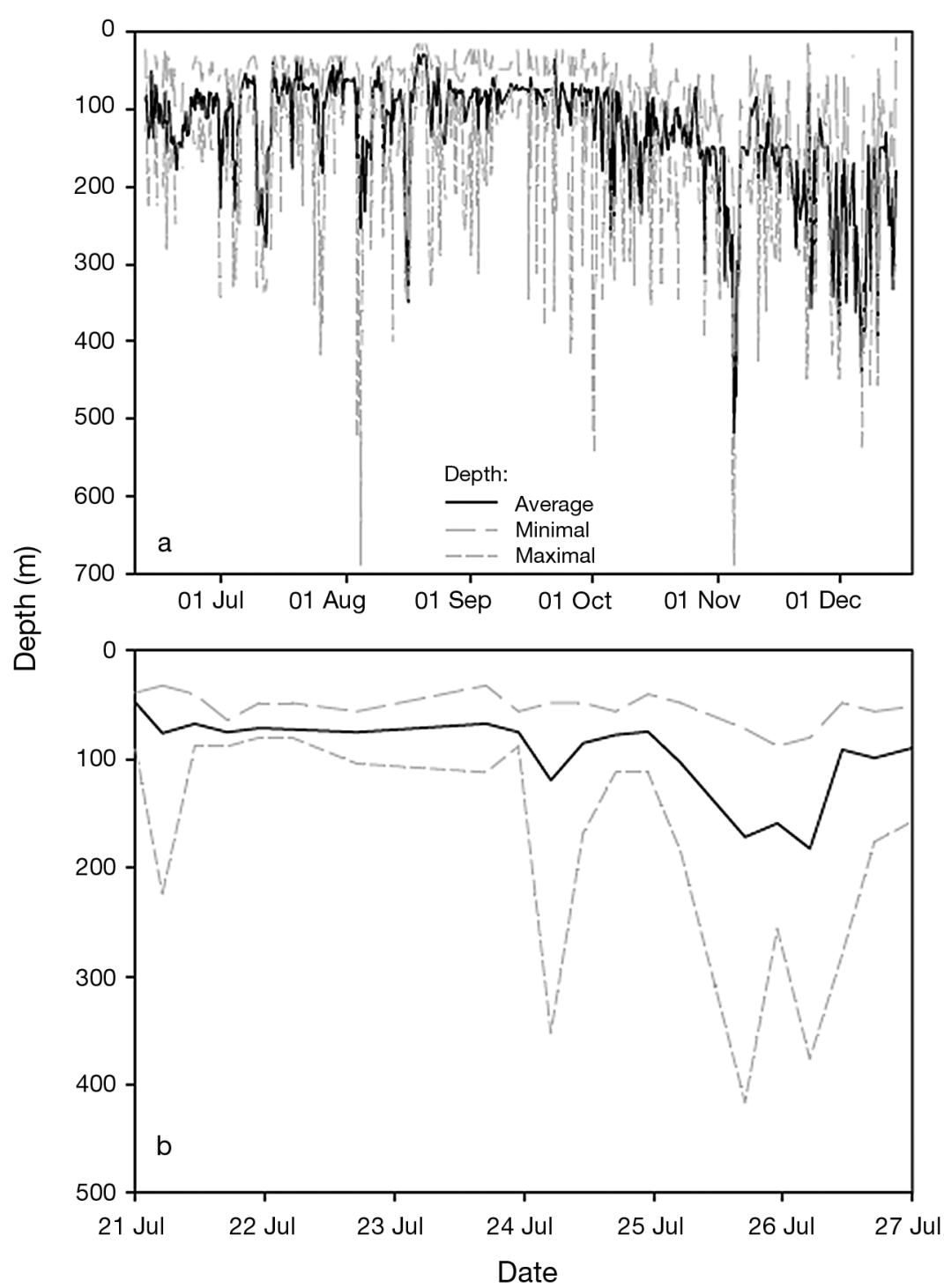

Fig. 3. Somniosus microcephalus. Average, minimum and maximum depths over (a) the time at liberty and (b) a 1 wk period in July for Greenland Shark 2008-5. This individual reported the most data; the profiles are similar to those of the other sharks records (Table 2). A mixed effects model using only shark identification number (null model) found that variation in mean temperature was comparable within individuals and among individuals. A second, full mixed effects covariate model provided similar results to depth; total length and time of day had little effect on temperature, but sex, month and the sex $\times$ month $\times$ interaction showed differences. The effect of sex on temperature was small overall $\left(<0.1^{\circ} \mathrm{C}\right)$ but, similar to the pattern with depth, differences between sexes varied with month. Males experienced more consistent temperatures across the months, although there was very little data in November ( $\mathrm{n}=5$, all $4.5^{\circ} \mathrm{C}$ ) and none for December. Males experienced warmer temperatures in June, July and August $\left(3.3 \pm 1.5,4.2 \pm 1.2\right.$ and $4.1 \pm 1.3^{\circ} \mathrm{C}$, respectively) compared to females (3.2 \pm $1.1,3.1 \pm 1.3$ and $3.5 \pm 1.7^{\circ} \mathrm{C}$, respectively). Males experienced colder temperatures in September and October $\left(4.3 \pm 1.3\right.$ and $4.0 \pm 0.6^{\circ} \mathrm{C}$, respectively) compared to females $(4.7 \pm 1.1$ and $4.6 \pm$ $0.6^{\circ} \mathrm{C}$, respectively). In November and December, females experienced temperatures $\left(4.7 \pm 0.6\right.$ and $4.3 \pm 0.7^{\circ} \mathrm{C}$, respectively) similar to those in September and October.

Similar to the depth pattern, sharks experienced a relatively broad range of temperature within each $6 \mathrm{~h}$ period, with a mean temperature variation of $1.2 \pm 0.9^{\circ} \mathrm{C}$ and a maximum of $5.8^{\circ} \mathrm{C}$ (Table 2, Fig. 4).

\section{DISCUSSION} experienced by the sharks over individual $6 \mathrm{~h}$ bin periods was $110 \pm 84 \mathrm{~m}$, but the range varied widely from 16 to $984 \mathrm{~m}$ (Table 2), suggesting significant up and down movements through the water column over relatively short periods of time (6 h) (Fig. 3).

The temperatures (all means $\pm \mathrm{SD}$ ) experienced by the Greenland sharks ranged from -1.5 to $7.4^{\circ} \mathrm{C}$ $\left(3.8 \pm 1.4^{\circ} \mathrm{C}\right)$, but mostly were between 3 and $5^{\circ} \mathrm{C}$ (Fig. 2, Table 2). Only 1 PAT (Shark 2009-2) reported sub-zero temperatures (including the low of $-1.5^{\circ} \mathrm{C}$ ), and although there were very few temperatures reported below $0.5^{\circ} \mathrm{C}$, most sharks experienced a temperature of $0^{\circ} \mathrm{C}$ at some point in their data
Archival pop-up satellite tags revealed that Greenland sharks in the High Arctic $\left(\sim 80^{\circ} \mathrm{N}\right)$ use a wide range of water depths (from surface to $>1500 \mathrm{~m}$ ), moving up and down through the water column over fairly short time periods $(6 \mathrm{~h})$. They experienced temperatures from -1.5 to $7.4^{\circ} \mathrm{C}$ and travelled significant distances $(>950 \mathrm{~km}$ ) but with no apparent migratory direction. The tagged sharks moved into deeper, warmer waters in the period from June through to December. No diel patterns were evident, and no relationships with total length were observed in 


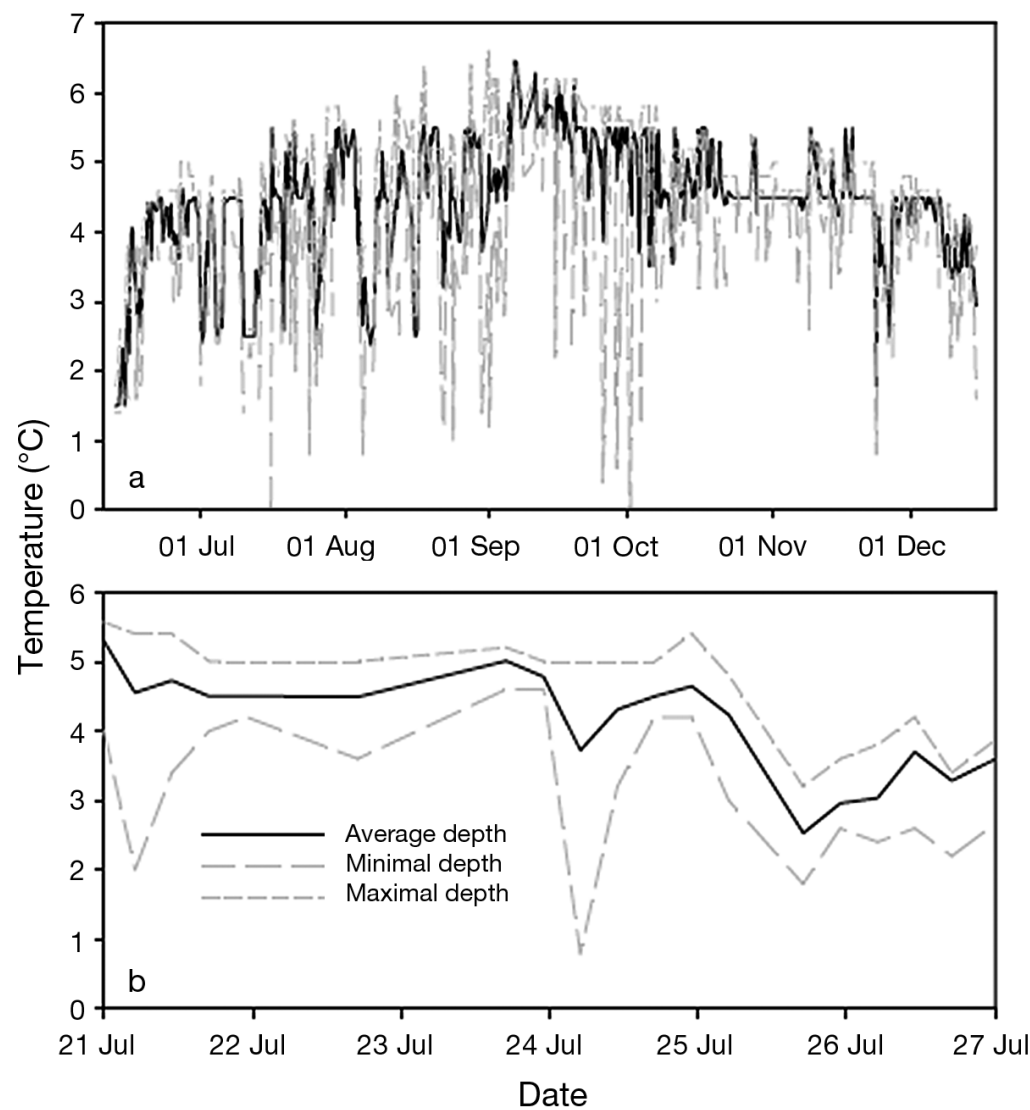

Fig. 4. Somniosus microcephalus. Average, minimum and maximum temperatures over the time at liberty in 2008 (a) and a 1 wk period in July (b) for Greenland Shark 2008-5. This individual reported the most data; the profiles are similar to those of the other sharks

either depth or temperature records, but it must be noted that the size range of the sharks in the present study was relatively limited, and all individuals were sexually immature. Overall, there was little difference in depth or temperature experienced by the 2 sexes, but on a monthly basis, males and females occupied different depths and experienced different temperatures. However, these differences were numerically small $\left(<30 \mathrm{~m}\right.$ and $\left.<1^{\circ} \mathrm{C}\right)$ in comparison to the total depth and temperature ranges experienced.

The general perception is that Greenland sharks are a benthic species, but this is clearly not their only habitat, or even the primary habitat, of immature individuals given the range of depths and the frequency of trips to the surface documented herein. The swimming depth of the sharks was $111 \pm 44 \mathrm{~m}$, which is similar to depths reported for other pelagic shark species, such as the blue shark Prionace glauca, although there was considerable inter-individual variance (Stevens et al. 2010, Campana et al. 2011). On average, males swam significantly deeper than females. Although this difference was minor overall $(<1 \mathrm{~m})$, it did vary depending on the month, with males swimming at deeper depths in June, July and October. However, there were few data points for males in November $(\mathrm{n}=5)$ and December $(\mathrm{n}=0)$, so conclusions about sex differences in these colder months are not possible.

The depth records for the Greenland sharks showed that they make regular movements up and down through the water column, as the minimum and maximum depths within $6 \mathrm{~h}$ time periods differed by $110 \pm 84 \mathrm{~m}$. This large variation in depth may reflect oscillatory swimming patterns, which are common in marine teleosts and elasmobranches; this pattern has been linked to prey searching or finding optimal temperature and oxygen levels (e.g. Sims et al. 2008, Nasby-Lucas et al. 2009). Watanabe et al. (2012) reports oscillatory dive patterns for a number of Greenland sharks that carried accelerometer tags for $24 \mathrm{~h}$. This swimming pattern has also been observed in Greenland sharks from the Canadian Arctic (Skomal \& Benz 2004) and the St. Lawrence Estuary (Stokesbury et al. 2005) as well as being documented in the closely related (Murray et al. 2008) Pacific sleeper shark Somniosus pacificus (Hulbert et al. 2006). This species is very similar to the Greenland shark in size and body shape (Yano et al. 2007).

The range of depth differences within $6 \mathrm{~h}$ periods was also highly variable, as all individual sharks had periods of low $(<64 \mathrm{~m})$ and high $(>216 \mathrm{~m})$ variation, with a maximum change of $984 \mathrm{~m}$ within a single $6 \mathrm{~h}$ period. Such variation in depth of swimming by Greenland shark has been noted in other studies (Skomal \& Benz 2004, Watanabe et al. 2012). Movement through the water column could be influenced by a variety of factors, such as prey availability, bathymetry or oceanographic variables. The PATs used do not provide data specific enough to identify whether dive behavior is oscillatory or to quantify the amplitude or regularity of potential oscillations.

Diet studies on Greenland sharks are consistent with an animal that feeds throughout the water column and suggest that the large variation in depths observed over $6 \mathrm{~h}$ periods might be related to searching for prey. Stomach content analysis of Greenland 
sharks collected in the same area and at the same time as the present study revealed that benthic fish species and marine mammals were the most commonly consumed prey (LeClerc et al. 2012). This is consistent with studies carried out in the Canadian Arctic (Fisk et al. 2002) and in Iceland (McMeans et al. 2010). As 9 of 14 sharks reached depths of $<16 \mathrm{~m}$, it is probable that they actively search for prey near the surface quite routinely. LeClerc et al. (2011) noted surface feedings in Greenland sharks which consumed floating blubber from harvested minke whales Balaenoptera acutorostrata. Skomal \& Benz (2004) suggested that Greenland sharks search for marine mammals in surface waters under sea ice, based on acoustic telemetry studies that showed sharks making numerous trips up into shallow water near or under sea ice. In our study, many of the PATs released close to ice edges, a hot spot for seals and marine mammals. Hulbert et al. (2006) also concluded that the time spent in shallow water by Pacific sleeper sharks was related to hunting for seals. Thus, evidence is building that sleeper sharks actively search for marine mammal prey, though it is clear that they also scavenge (LeClerc et al. 2011).

The depth of $1560 \mathrm{~m}$, achieved by 1 of the tagged Greenland sharks in Svalbard, is the greatest confirmed depth for this species. This individual may have gone deeper, but the built-in depth protection device released the tag. Sharks that were thought to be Greenland sharks were reported at greater depths $(>2000 \mathrm{~m}$ ) off Georgia, USA (Herdendorf \& Berra 1995), and in the Gulf of Mexico, but these individuals have not been confirmed to be Somniosus microcephalus (Benz et al. 2007). But, in any case, it is clear that Greenland sharks can achieve depths $>1500 \mathrm{~m}$, placing this species among the deepest diving sharks (Priede et al. 2006).

Greenland sharks experienced temperatures between -1.5 and $7.4^{\circ} \mathrm{C}$ in this study but were usually found in the 3 to $5^{\circ} \mathrm{C}$ range. Male sharks were on average found in warmer water than females, but the sex-related difference in temperature was small $\left(<1^{\circ} \mathrm{C}\right)$ and varied with month. Males stayed at a more consistent temperature from June to October, while females moved from colder temperatures in summer (June to August) to warmer temperatures during fall and early winter (September to December). The water temperatures recorded from Svalbard were similar to the temperature range reported for Greenland sharks in the St Lawrence Estuary $\left(-1.1\right.$ to $\left.8.6^{\circ} \mathrm{C}\right)$ (Stokesbury et al. 2005). Greenland sharks can deal with temperatures $<0^{\circ} \mathrm{C}$ (Skomal \& Benz 2004). Tolerating such cold temperatures makes the Greenland shark unique among ectothermic sharks (see also Stokesbury et al. 2005, Watanabe et al. 2012); the Pacific sleeper shark in the north-east Pacific Ocean has not been reported to experience temperatures $<4.4^{\circ} \mathrm{C}$ (Hulbert et al. 2006). The high tolerances to both cold and depth means that the geographic range of the Greenland shark could extend much further north (and south, by travelling in deep cold water) than is currently documented.

The average, minimum and maximum depths and temperatures of the Greenland sharks showed no relationship to time of day. However, because data were binned into $6 \mathrm{~h}$ time periods and fewer data were available during periods of light and dark, these results should be viewed with caution, and this topic requires further study. Also, ambient light levels, ranging from $24 \mathrm{~h}$ light to $24 \mathrm{~h}$ dark in the study period, may be the reason for the lack of pattern on the $24 \mathrm{~h}$ cycle in this study, but more specific depth records over shorter time periods are required. The apparent lack of a diel pattern is in contrast to many other shark species that commonly show quite marked diel vertical movement patterns (Weng \& Block 2004, Sims et al. 2005, Weng et al. 2007, Andrews et al. 2009), including the Pacific sleeper shark (Hulbert et al. 2006, but also see Brunnschweiler et al. 2010). There is some evidence that Greenland sharks display diel movement patterns in the St. Lawrence Estuary, although not at all locations in the area (Stokesbury et al. 2005); however, the sample size was only 3 sharks (Stokesbury et al. 2005).

There appeared to be no specific pattern to the direction of Greenland shark movements based on the tags' pop-off locations, although in general, most sharks moved northward from the release sites. Five sharks moved a considerable distance to the east. Both the easternmost $\left(40.8^{\circ} \mathrm{E}\right)$ and northernmost $\left(82.4^{\circ} \mathrm{N}\right)$ locations represent the extremes reported to date for this species' distribution. There is no obvious barrier to Greenland sharks moving further in both of these directions, and they may well be prevalent throughout the Arctic Ocean; unfortunately, there are almost no data on fish in the Arctic Ocean. Arctic waters above the Bering Strait would be of particular interest because the distributions of the 2 Somniosus species could potentially overlap in this region (see Benz et al. 2004). To date, no Greenland sharks have been found in Pacific waters, and no Pacific sleeper sharks have been observed in Atlantic waters.

The distance travelled and the crude rate of travel calculations varied greatly among the Svalbardtagged Greenland sharks. However, neither of these metrics is actually measured directly by the PATs; 
only crude approximations are possible from the time and place of marking versus the tag release position and time. Very few light data $(<20$ data points across a number of sharks) were collected by the tags in the present study, and these data made no sense when estimates of latitude and longitude were computed, so even crude geolocation data are not available. It seems likely that sharks that had the PATs pop-off near the tagging site had actually moved away but returned to the tagging area, as most of these sharks had experienced deeper depths than would be possible in the tagging area.

Greenland sharks from Svalbard (the present study) and western Greenland (Hanson 1963) had greater displacement distances than those reported for Pacific sleeper sharks (Hulbert et al. 2006), although it must be noted that the Pacific sleeper shark tags were deployed for a shorter period $(<50 \mathrm{~d})$. However, the greatest distance travelled by a Svalbard Greenland shark is much smaller than has been recorded for many other shark species, some of which make trans-ocean migrations (Block et al. 2011). But given the limited deployment times of the tags in the present study, the range that Greenland sharks travel on an annual basis might be great, and further study of their movement patterns is certainly warranted.

The greatest rate of travel achieved according to time and total displacement was $16.6 \mathrm{~km} \mathrm{~d}^{-1}$ (Shark 2009-7). This is less than half the average $\left(0.34 \mathrm{~m} \mathrm{~s}^{-1}\right)$ and one-quarter of the maximum $\left(0.73 \mathrm{~m} \mathrm{~s}^{-1}\right)$ swimming speed measured using accelerometers over a $24 \mathrm{~h}$ period (using many of the same sharks as the present study) (Watanabe et al. 2012), so clearly, there is considerable up and down movement combined with non-linear paths. Shark 2009-7 had one of the shallowest maximum depths $(352 \mathrm{~m})$ but swam $>500 \mathrm{~km}$ from the tagging location into the shallow Barents Sea. This individual also had the lowest mean depth differences over the $6 \mathrm{~h}$ bin periods $(79 \mathrm{~m})$, which indicates that the Greenland shark may be able to modify behavior such that they can travel significant distances more quickly. However, the rate of travel is clearly much slower than fastswimming shark species found in warmer waters (Sundström et al. 2001, Saunders et al. 2011).

The number of PATs that reported data was poor compared to similar deployments on other shark species. In 48 previous shark PAT studies the failure rate (i.e. no reporting by the tag) of tags was generally low (Hammerschlag et al. 2011). However, since many of the sharks moved north and east, it is likely that the PATs that did not report were released under sea ice, which is very prevalent in this direction from
Svalbard (see AMSR-E Sea Ice Maps) (Spreen et al. 2008). The most northerly and easterly reporting tags (Shark 2009-M), popped up in an area with 75 to $100 \%$ ice cover (AMSR-E Sea Ice Maps) (Spreen et al. 2008). Some other tags also reported from areas very close to ice edges, and a number of them for the first time a few days after the set release date and often with very small amounts of data $(<1 \%)$, suggesting they had been under ice for several days. Reporting rates for tags in temperate and tropical locations are usually higher; for example, 18 of 20 PATs attached to bull sharks Carcharhinus leucas in sub-tropical waters reported (Brunnschweiler et al. 2010), as did 37 of 40 PATs for blue sharks Prinonace glauca in the North Atlantic (Campana et al. 2011). The use of pop-off tags in Arctic waters with yearround ice is an obvious challenge.

A number of the PATs popped off prematurely, which is not uncommon for this type of tag when used on sharks (see Hulbert et al. 2006, Chapman et al. 2007, Hammerschlag et al. 2011). Other studies attribute premature release of tags to poor insertion or anchoring of tags, which are often deployed by divers on free-moving individuals (Brunnschweiler et al. 2010). This was not the case in the present study. One explanation for premature release of tags could be the death of the individual, but we have no evidence of this in the movement data. In 2008, tags were programmed to release if a constant depth was maintained over $4 \mathrm{~d}$, but none of the premature releases indicated this (2009 tags had this function disabled). Results from the 6 Greenland sharks monitored continuously for $24 \mathrm{~h}$ after release (Watanabe et al. 2012) and diver observations of all tagged sharks in 2009 showed consistent and sustained swimming following release. The lowly calcified cartilage of the Greenland shark might contribute to the premature releases of the tags, as the cartilage of the pterygiophores may hold better in shark species with greater calcification.

Using PATs, we demonstrated that Greenland sharks move widely and forage throughout the water column in High Arctic waters around Svalbard, Norway. These sharks occupied depths from the surface to $>1500 \mathrm{~m}$ and temperatures from -1.5 to $7.4^{\circ} \mathrm{C}$. There was no evidence of diel patterns by the sharks but their depth and temperatures decreased from June to December. Most tags popped-off within $500 \mathrm{~km}$ of the tagging location, but 2 sharks moved 720 and $980 \mathrm{~km}$ to the northeast. These data represent the deepest confirmed depth and the most northerly and easterly locations of these large coldwater elasmobranches. 
Acknowledgements. We thank G. Christensen, K. Frost, L. LeClerc, L. Lowry, H. Lund, B. McMeans, K. Molde, Y. Watanabe, and the crew on the RVs 'Lance' and 'Viking Explorer' for their help in the field and N. Hussey and A. MacNeil for comments on the manuscript and statistical advice. This work was funded by the Research Council of Norway (grant number 184644), the Norwegian Polar Institute and the Canadian Research Chair program. Permits to conduct this research were provided by the Norwegian Animal Research Authority.

\section{LITERATURE CITED}

Andrews KS, Williams GD, Farrer D, Tolimieri N, Harvey CJ, Bargmann G, Levin PS (2009) Diel activity patterns of sixgill sharks, Hexanchus griseus: the ups and downs of an apex predator. Anim Behav 78:525-536

Benz GW, Hocking R, Kowunna A, Bullard SA, George JC (2004) A second species of Arctic shark: Pacific sleeper shark Somniosus pacificus from Point Hope, Alaska. Polar Biol 27:250-252

Benz GW, Hoffmayer ER, Driggers WB, Allen D, Bishop LE, Brown DA (2007) First record of a sleeper shark in the western Gulf of Mexico and comments on taxonomic uncertainty within Somniosus (Somniosus). Bull Mar Sci 80:343-351

> Block BA (2005) Physiological ecology in the 21st century: advancements in biologging science. Integr Comp Biol 45:305-320

Block BA, Jonsen ID, Jorgensen SJ, Winship AJ and others (2011) Tracking apex marine predator movements in a dynamic ocean. Nature 475:86-90

Brunnschweiler JM, Queiroz N, Sims DW (2010) Oceans apart? Short-term movements and behaviour of adult bull sharks Carcharhinus leucas in Atlantic and Pacific Oceans determined from pop-off satellite archival tagging. J Fish Biol 77:1343-1358

Campana SE, Dorey A, Fowler M, Joyce W, Wang Z, Wright D, Yashayaev I (2011) Migration pathways, behavioural thermoregulation and overwintering grounds of blue sharks in the Northwest Atlantic. PLoS ONE 6:e16854

> Chapman DD, Pikitch EK, Babcock EA, Shivji MS (2007) Deep-diving and diel changes in vertical habitat use by Caribbean reef sharks Carcharhinus perezi. Mar Ecol Prog Ser 344:271-275

> Dunbar MJ, Hildebrand HH (1952) Contribution to the study of fishes of Ungava Bay. J Fish Res Board Can 9:83-128

Fisk AT, Tittlemier SA, Pranschke JL, Norstrom RJ (2002) Using anthropogenic contaminants and stable isotopes to assess the feeding ecology of Greenland sharks. Ecology 83:2162-2172

> Hammerschlag N, Gallagher AJ, Lazarre DM (2011) A review of shark satellite tagging studies. J Exp Mar Biol Ecol 398:1-8

Hansen PM (1963) Tagging experiments with the Greenland Shark (Somniosus microcephalus (Bloch and Schneider) in Subarea 1. Int Comm Northwest Atl Fish Spec Publ 4: 172-175

> Herdendorf CE, Berra TM (1995) A Greenland shark from the wreck of the SS Central-America at 2,200 m. Trans Am Fish Soc 124:950-953

Hoel A (1949) Håkjerringfisket i Arktiske farvann (Greenland shark fisheries in Arctic waters). In: Strøm J (ed) Særtrykk av Norsk Fiskeri og Fangst Håndbok. Bind I del III. Albert Cammermeyers, Oslo, p 823-828

Hulbert LB, Sigler MF, Lunsford CR (2006) Depth and movement behaviour of the Pacific sleeper shark in the northeast Pacific Ocean. J Fish Biol 69:406-425

Jensen AS (1948) Contribution to the ichthyofauna of Greenland 8-24. Skrifter udgivet af Universitets Zoologiske Museum, København, Spolia Zoologica Musei Hauniensis 9:1-182

Johannessen OM, Miles MW (2010) Critical vulnerabilities of marine and sea ice-based ecosystems in the high Arctic. Reg Environ Change 11:S239-S248

> Kovacs KM, Lydersen C, Overland JE, Moore SE (2011) Impacts of changing sea-ice conditions on Arctic marine mammals. Mar Biodiversity 41:181-194

Kovacs KM, Aguilar A, Aurioles D, Burkanov V and others (2012) Global threats to pinnipeds. Mar Mamm Sci 28: 414-436

LeClerc LM, Lydersen C, Haug T, Gover KA, Fisk AT, Kovacs KM (2011) Greenland sharks (Somniosus microcephalus) scavenge offal from minke (Balaenoptera acutorostrata) whaling operations in Svalbard (Norway). Polar Res 30:7342

> LeClerc LME, Lydersen C, Haug T, Bachmann L, Fisk AT, Kovacs KM (2012) A missing puzzle piece in Arctic food webs? Greenland sharks (Somniosus microcephalus) as predators of Arctic marine mammals in Svalbard, Norway. Polar Biol 35:1197-1208

> MacNeil MA, McMeans BC, Hussey N, Vecsei P and others (2012) Biology of the Greenland shark Somniosus microcephalus (Bloch and Schneider, 1801). J Fish Biol 80: 991-1018

McMeans B, Svavarson J, Dennard S, Fisk AT (2010) Diet and resource use among Greenland sharks (Somniosus microcephalus) and teleosts sampled in Icelandic waters, using $\delta^{13} \mathrm{C}, \delta^{15} \mathrm{~N}$, and mercury. Can J Fish Aquat Sci 67 : 1428-1438

Murray BM, Wang JY, Yang SC, Stevens JD, Fisk A, Svavarsson J (2008) Mitochondrial cytochrome b variation in sleeper sharks (Squaliformes: Somniosidae). Mar Biol 153:1015-1022

> Nasby-Lucas N, Dewar H, Lam CH, Goldman KJ, Domeier ML (2009) White shark offshore habitat: a behavioral and environmental characterization of the Eastern Pacific Shared Offshore Foraging Area. PLoS ONE 4:e8163

> Pershing AJ, Christensen LB, Record NR, Sherwood GD, Stetson PB (2010) The impact of whaling on the ocean carbon cycle: why bigger was better. PLoS ONE 5: e12444

Priede IG, Froese R, Bailey DM, Bergstad OA and others (2006) The absence of sharks from abyssal regions of the world's oceans. Proc Biol Sci 273:1435-1441

R Development Core Team (2010) R: a language and environment for statistical computing. R Foundation for Statistical Computing, Vienna. www.R-project.org

> Saunders RA, Royer F, Clarke MW (2011) Winter migration and diving behaviour of porbeagle shark, Lamna nasus, in the Northeast Atlantic. ICES J Mar Sci 68:166-174

> Sims DW, Southall EJ, Tarling GA, Metcalfe JD (2005) Habitat-specific normal and reverse diel vertical migration in the plankton-feeding basking shark. J Anim Ecol 74: 755-761

Sims DW, Southall EJ, Humphries NE, Hays GC and others (2008) Scaling laws of marine predator search behaviour. Nature 451:1098-1102

Skomal GB, Benz GW (2004) Ultrasonic tracking of Green- 
land sharks, Somniosus microcephalus, under Arctic ice. Mar Biol 145:489-498

Spreen G, Kaleschke L, Heygster G (2008) Sea ice remote sensing using AMSR-E $89 \mathrm{GHz}$ channels. J Geophys Res 113:C02S03, doi: 10.1029/2005JC003384

Stevens JD, Bradford RW, West Grant J (2010) Satellite tagging of blue sharks (Prionace glauca) and other pelagic sharks off eastern Australia: depth behaviour, temperature experience and movements. Mar Biol 157:575-591

Stokesbury MJW, Harvey-Clark C, Gallant J, Block BA, Myers RA (2005) Movement and environmental preferences of Greenland sharks (Somniosus microcephalus) electronically tagged in the St. Lawrence Estuary, Canada. Mar Biol 148:159-165

Sundström LF, Gruber SH, Clermont SM, Correia JPS, de Marignac JRC (2001) Review of elasmobranch behavioural studies using ultrasonic telemetry with special reference to the lemon shark, Negaprion brevirostris, around Bimini Islands, Bahama. Environ Biol Fish 60:

Editorial responsibility: Christine Paetzold, Oldendorf/Luhe, Germany
225-250

Templeman W (1963) Distribution of sharks in the Canadian Atlantic (with special reference to Newfoundland waters). Bull Fish Res Board Can 140:36-42

> Watanabe Y, Lydersen C, Fisk AT, Kovacs KM (2012) The slowest fish: swim speed and tail-beat frequency of Greenland sharks. J Exp Mar Biol Ecol 426-427:5-11

Weng KC, Block BA (2004) Diel vertical migration of the bigeye thresher shark (Alopias superciliosus), a species possessing orbital retia mirabilia. Fish Bull 102:221-229

Weng KC, Boustany AM, Pyle P, Anderson SD, Brown A, Block BA (2007) Migration and habitat of white sharks (Carcharodon carcharias) in the eastern Pacific Ocean. Mar Biol 152:877-894

Yano K, Stevens JD, Compagno LJV (2007) Distribution, reproduction and feeding of the Greenland shark Somniosus (Somniosus) microcephalus, with notes on 2 other sleeper sharks, Somniosus (Somniosus) pacificus and Somniosus (Somniosus) antarcticus. J Fish Biol 70:374-390

Submitted: November 28, 2011; Accepted: July 25, 2012 Proofs received from author(s): November 6, 2012 